\title{
O livro por vir: anotações sobre a escritura no Livro do desassossego
}

\author{
Elaine Cristina Cintra \\ Universidade Federal de Uberlândia
}

\section{Dispersão e movimento: O livro por vir}

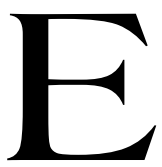

m sua obra O livro por vir, Maurice Blanchot discorre sobre um canto que está a se fazer, tal como aquele das sereias que encantou o homérico Ulisses. Este canto, supremo índice do sublime, é forma que escorre entre os dedos e que leva sempre a um espaço inalcançável, sempre distante, é o intervalo entre o real e o imaginário, o lugar de convivência entre o absoluto e o absurdo, ou seja: o livro, o "mais belo dos mundos possíveis". ${ }^{1}$ Este livro por vir está materializado, na opinião de Blanchot, no projeto de Mallarmé, que, a partir de 1866, concentrou-se em arquitetar aquilo que seria o plano de seu Livro, obra que representaria o tudo e o nada de sua produção poética. Em "O livro, instrumento espiritual", o poeta francês impunha uma regra estética: que "tudo, no mundo, exista para terminar num livro". 2 Cabe-nos aqui advertir, porém, que para o autor francês "o livro" é texto, seja uma frase, um fragmento, ou qualquer palavra que se constitua em uma máquina de sentidos:

Nada de fortuito, lá, onde aparece um acaso captar à idéia, a aparelhagem é a mesma: não julgar, em conseqüência, esses propósitos - industriais ou tendo que ver com alguma materialidade:

${ }^{1}$ BLANCHOT, 2005, p. 10.

2 MALLARMÉ,1991, p. 125. 
a fabricação do livro, no conjunto que desabrochará, começa, a partir de uma frase. Imemorialmente o poeta dentro desse verso, no soneto que se inscreve para o espírito ou sobre espaço puro. Da minha parte, desconheço o volume e uma maravilha que intima sua estrutura, se não posso, ciosamente, imaginar tal motivo em vista de um lugar especial, página e a altura, à orientação do dia, a sua, ou quanto à obra. Mais o vai-e-vem sucessivo incesssante do olhar, termina uma linha, à seguinte, para recomeçar: semelhante prática não representa a delícia, tendo, imortalmente, rompido, uma hora, com tudo, de traduzir sua quimera. Senão ou salvo execução, como trechos sobre um teclado, ativa, medida pelas folhas - que não se fecham os olhos a sonhar? Presunção essa nem servidão fastidiosa: mas a iniciativa, cujo clarão está em todos, interliga a notação fragmentada. ${ }^{3}$

Tal livro mallarmeano, que nunca chegou de fato a se concretizar apesar de toda configuração arquitetônica que seu autor lançou em vários esboços, teria que ser totalmente planejado, construído contra o imprevisto, o acaso, e intrinsecamente voltado para si próprio, excluindo aspectos da realidade em uma linguagem de "ausência e de negação", ${ }^{4}$ sem autor e tão impessoal que Blanchot lembra que, em alguns textos, Mallarmé afirma que o livro deverá ser anônimo: "este não pode atribuirse aquilo que escreve. E aquilo que escreve, mesmo que sob seu nome, permanece essencialmente sem nome". 5 O livro por vir, projeto inacabado de Mallarmé, ${ }^{6}$ pode ser visto como um dos desdobramentos criativos mais instigantes de Fernando Pessoa, uma vez que seu Livro do desassossego fica submerso em um canto sublime, em que os fragmentos se ritualizam no fazer e refazer textual, distância sempre a ser alcançada, eterna possibilidade de recomeço a cada leitura. Assim a "idéia" do Livro que acompanhou Pessoa por toda sua vida literária será, na verdade, o Livro, não o que o vocábulo convencionalmente sugere como tal, mas o livro mallarmeano, que é e não é ao mesmo tempo. Atento a seu tempo, F. Pessoa redefine o ser (aqui, no caso, do livro) como projeto em movimento, projeto esse que o acompanhou, tal como em Mallarmé, por

${ }^{3}$ MALLARMÉ, 1991, p. 125.

${ }^{4}$ BLANCHOT, 2005, p. 330.

${ }^{5}$ BLANCHOT, 2005, p. 331-332.

${ }^{6}$ Para Blanchot, o livro mallarmeano realiza-se no poema "Um lance de dados". 
toda a vida. O Livro de Pessoa é constituído de espaços intervalares, que giram em torno do espaço macrocósmico de uma cidade no início do século ou o espaço do microcosmo interior de um citadino comum. Mas cabe lembrar que o Livro do desassossego é principalmente um espaço para o exercício da escrita, e se Vicente Guedes, um de seus heteroautores, era um livro, Bernardo Soares, o semi-heterônimo que lhe assumiu a autoria final, vive duplamente de escrever, tanto em seu ofício de guarda-livros, como em sua atividade extra-cotidiana, de redigir um livro sobre suas sensações. Neste sentido, tanto Pessoa quanto Mallarmé, seu antecessor, redimensionam a palavra livro como um lugar, em que os textos decorrem conforme a necessidade do leitor. Este lugar, território movente, só se institui se for distância a ser percorrida, fato que Blanchot adivinha em seus escritos sobre o livro que está sempre a caminho. A proposta deste ensaio é, então, verificar como a escritura ${ }^{7}$ do Livro do desassossego, obra em prosa de Fernando Pessoa, constitui-se em um exemplo marcante daquilo que Blanchot chama de "mundo disperso", ou uma literatura que está localizada no devir, e que, marcada pelas especulações de Mallarmé sobre o projeto maior de sua obra, apresenta a realização do belo eterno, o canto inapreensível que se encontra sempre aquém de qualquer parte. Desta forma, apresento esta obra como a realização material do projeto mallarmeano, através da leitura de Blanchot sobre a literatura que emerge do movimento de dispersão e negação.

Para tanto, proponho verificar como este livro a caminho se inscreve a partir de várias perspectivas, valendo, para isto, reconsiderar não só a problemática do gênero literário, mas também a gênese de suas publicações, já que esta polêmica se estabelece desde as primeiras tentativas de organização, e, como work in progress, traz o leitor para o lugar de co-criador. O texto pessoano é mais além, fora de qualquer fronteira, e dialoga com olhares estrangeiros a si, híbridos, não usuais e, por isso, constante surpresa e afirmação do novo.

\footnotetext{
7 A palavra "escritura" aqui é usada no sentido barthesiano de palavra em movimento, com sentidos espiralados, formando uma escrita-entre e um textofruição.
} 


\section{Os livros do Livro}

Livro que se refaz diferentemente a cada edição, esta obra pessoana recebeu de seus críticos inúmeros epítetos: "livro-caixa" e "livrosensação", ${ }^{8}$ "diário fingido", "prosa enclausurada", ${ }^{10}$ "diário metafísico da mediocridade humana", ${ }^{11}$ "livro perverso", ${ }^{2}$ "livro-síntese", ${ }^{13}$ "drama em gente", ${ }^{14}$ "o grande testamento imaginário de Fernando Pessoa". ${ }^{15}$ Para o próprio poeta, esse livro também se apresenta diverso: em alguns trechos ele o denomina "livro inútil", ${ }^{16}$ "autobiografia de quem nunca existiu", ${ }^{17}$ "livro absurdo", ${ }^{18}$ "torre do silêncio das minhas ânsias", ${ }^{19} \mathrm{e}$ assim por diante. Fernando Pessoa escreveu o Livro do desassossego de 1913 a 1935, praticamente durante toda a sua vida literária, mas não chegou jamais a organizá-lo em sua forma definitiva. Obra em aberto, ela admite várias possibilidades de leitura, e a cada edição, algo se lhe acrescenta, subtrai-lhe ou se lhe modifica. Assim, mais do que qualquer outro texto de Pessoa, o Livro do desassossego é uma espiral de fragmentos em constante mutação, em que a própria palavra livro demonstra ser problemática, tanto quanto o gênero a que pertence.

Denominando-se um livro, na verdade, esta obra pessoana não se constitui literalmente como tal, sendo composto por uma série de fragmentos que não chegaram a ser organizados de forma conclusiva por seu autor. O Livro do desassossego ficou, assim, de maneira inexorável,

\footnotetext{
${ }^{8}$ MOISÉS, 1988, p. 87.

${ }^{9}$ PAIVA, 1988, p.90.

${ }^{10}$ KUJAWSKI, 1988, p. 283.

${ }^{11}$ TABUCCHI, 1984, p. 114.

${ }^{12}$ PERRONE-MOISÉS, 1988, p. 86.

${ }^{13}$ PAIVA, 1988, p. 92.

${ }^{14}$ LOURENÇO, 1986, p. 67.

${ }^{15}$ RUBIM, 2000, p. 216.

${ }^{16}$ GUEDES; SOARES, 1994, p. 21.

${ }^{17}$ GUEDES; SOARES, 1994, p. 19.

${ }^{18}$ GUEDES; SOARES, 1994, p. 21.

${ }^{19}$ GUEDES; SOARES, 1994, p. 21.
} 
marcado pela incompletude e dispersão, - uma escrita a caminho, um projeto de escrita, um intervalo entre aquilo que já não é o nada, mas não chega a ser algo, ou melhor, um "livro de sonho", como Guedes e Soares, em vários trechos, o denominam. Sonho porque não se realiza e porque é escrito em um estado-entre: entre a vigília e o sono, entre a consciência e a inconsciência, entre a poesia e a prosa. ${ }^{20}$ Como intervalo de obra, este livro realiza o canto da sereia de Blanchot e torna-se vislumbre, mas não objeto a ser plenamente atingido.

Essa constante mobilidade de fragmentos, sentidos e imagens imprime inquietações que já podem ser notadas na gênese da obra: em diferentes datas, Fernando Pessoa escreveu a amigos sobre trechos que estava compondo para o Livro. Em 1914, em uma carta a Armando CortesRodrigues, comenta seu estado de espírito repleto de uma "depressão profunda e calma" que caracterizaria o estilo do Livro. Em 1932, escreve a João Gaspar Simões anunciando a intenção de publicar o Livro do desassossego, mas somente depois de efetuar uma revisão cautelosa. Percebemos assim que, tal como o projeto de Mallarmé, o Livro é cuidadosamente arquitetado, projetado para não dar vez ao acaso.

Essa preocupação em refazer o Livro fica bem explícita em um fragmento não-datado a respeito da organização da obra, no qual afirma que ela deveria conter "trechos variadamente existentes", mas adaptados à psicologia de Soares; em sua "expressão íntima", nele deveriam constar o devaneio e a "desconexão lógica". Os textos longos ele pensa publicálos à parte, ou agregá-los aos outros fragmentos para formar um "diário íntimo". Projetos - nada que se concretizou de fato.

Gustavo Rubim aponta para a problemática de se chamar "livro" a essa coletânea de fragmentos - esse leitor de Pessoa afirma que a palavra adquire um status importante ao ser imprimida no título da obra, mas, nesse caso, tal vocábulo é duvidoso, uma vez que pressupõe unidade e acabamento. Assim, no sentido estrito da palavra "livro", essa obra de Fernando Pessoa não existiria:

Isto equivale a dizer que, entre o único que nunca foi nem será e os vários em que desde sempre se multiplicou, o Livro do desassossego em boa verdade não existe. Não existe como livro, mero livro, um

${ }^{20}$ Este aspecto intermediário de prosa poética foi estudado em artigo de Raúl Romero e René P. Garay, 2005. 
livro entre outros, um livro simplesmente inacabado ou um projecto de livro interrompido na sua realização. ${ }^{21}$

O Livro do desassossego se mostra, então, como projeto, como literatura a caminho, o que foi notado por Jacinto do Prado Coelho (1982), já na primeira edição do Livro, quando preveniu seus leitores sobre este estado de obra inacabada, coleção de fragmentos ora incompletos, ora aparentando forma definitiva, dispersos e contraditórios, algumas vezes. José Blanco e Maria Alzira Seixo (1986), na apresentação crítica da edição que compuseram, discutem também a questão do Livro pessoano ser e não ser, concomitantemente, um livro: os críticos afirmam que no sentido estrito da palavra, como obra acabada, a obra de Soares e Guedes não constitui por si um livro, entretanto, ela traz em sua longa e constante elaboração, a gênese de um livro. Livro ou não, são vários os livros denominados Livro do desassossego e, a cada vez que uma nova edição surge, dilui-se ainda mais a idéia de que haverá uma edição definitiva. Assim, desde 1913, temos várias possibilidades de Livro, ou melhor, vários livros. Apesar da estréia inquietante de "Na Floresta do Alheamento", somente em 1929 Fernando Pessoa volta a publicar trechos do Desassossego, e assim o fará até 1932, em revistas literárias como Solução Editora, Presença e Descobrimento. De todo o Livro, ou dos vários que se iriam compondo através dos diferentes organizadores, doze trechos foram publicados pelo autor em vida, o que constitui uma amostra minúscula da quantidade ainda por se organizar de textos que supostamente formariam o aglomerado de tal livro. Mas, mesmo sem publicar, durante todo esse período, o autor manteve um exercício constante e nada conclusivo de escrita, reescrevendo, revigorando e adaptando trechos que destinaria à composição de seu "Livro"; êxito malogrado, porém, pela enorme dispersão que o acompanhava. De uma forma ampla, poderíamos montar o seguinte quadro das principais edições, até então, do Livro do desassossego:

1982: a publicação da edição princeps pela Editora Ática, organizada e prefaciada por Jacinto do Prado Coelho, com a colaboração de Maria Aliete Galhoz e Teresa Sobral Cunha;

1986: a publicação pela Editora Europa-América da edição em dois volumes, organizada por António Quadros;

${ }^{21}$ RUBIM, 2000, p.218. 
1991: a publicação pela Editorial Presença da edição em dois volumes organizada por Teresa Sobral Cunha;

1992: a edição inglesa traduzida e organizada por Richard Zenith, pela Editora Carcanet e Fundação Calouste Goulbenkian;

1994: a reedição ampliada da edição de 1991, publicada pela UNICAMP em dois volumes e prefaciada por Haquira Osakabe.

1997: o primeiro volume da edição organizada por Teresa Sobral Cunha, pela Editora Relógio d’Água (1997), com inéditos;

1998: a edição "oficial” organizada por Richard Zenith, pela Editora Assírio \& Alvim, e reeditada pela Editora Companhia das Letras em 1999.

A edição princeps, publicada pela Editora Ática em 1982, constituise dos vários fragmentos do espólio Fernando Pessoa que estão marcados com o sinal $L$. do D. (aproximadamente 450 trechos), que indica a intenção literária a que se destinavam (sempre duvidosa, tratando-se desse autor). Mas, mesmo esse número reduzido de fragmentos, tendo em vista as edições posteriores, apresentou a seus organizadores um considerável emaranhado de problemas quanto à autoria e a legibilidade. O Livro do desassossego, desde sua primeira edição, foi objeto de angústia e polêmicas entre os críticos.

Em sua introdução à edição espanhola, Ángel Crespo (1984) conta que a partir de 1960, Jorge de Sena, estabelecido no Brasil, iniciou a negociação com a Ática para a publicação dos originais do Livro. Com a ajuda de Maria Aliete Galhoz, que em Lisboa dedicava-se a compilar e organizar o material, além de enviar para o professor as fotocópias dos fragmentos, Sena comprometeu-se com a editora a entregar o livro até janeiro de 1964. No entanto, em dezembro desse ano, Sena desculpouse com a editora por não haver cumprido o prazo do contrato, pelas enormes dificuldades que os originais ofereciam, tanto para transcrição de trechos manuscritos, como pelo fato de o material estar disperso e fragmentado. Assim, Jorge de Sena firmou novo contrato, dessa vez para julho de 1965, mas, quando já havia escrito uma considerável introdução para o livro, Georg Rudolf Lind escreve-lhe contando haver encontrado mais de 100 trechos manuscritos, assinalados com L. do D. Sena, então, afasta-se do projeto, concluído por Jacinto do Prado Coelho, responsável pela organização do material, com a ajuda de Maria Aliete Galhoz e Teresa 
Sobral Cunha, que recolherão e transcreverão os trechos e suas variantes. Mesmo assim, somente em 1982, o projeto se conclui.

No entanto, em sua introdução, Jacinto do Prado Coelho admite não ser essa a obra definitiva desse prosador de F. Pessoa, e conclui aquilo que será a polêmica nuclear do Livro: há nesse livro não uma só obra, mas várias, de diferentes estilos.

Nesta mesma introdução, o organizador do primeiro Livro atenta também para o fato de que essa obra traz em si o cerne de todo o universo pessoano, constituindo-se centro de encontro dos vários heteropoetas. Obra sintética, o Livro do desassossego apresentaria todas as vozes de F. Pessoa, tanto as poéticas quanto as ensaísticas, marca também que se apresenta fundamental no projeto mallarmeano do Livro.

Essa primeira edição rejeitará o critério cronológico, optando por investigar as aproximações temáticas, que marcariam com mais ênfase o caráter difuso e heterodoxo do Livro, como ficou explícito na introdução de Coelho. A organização dessa edição provocará algumas reações opositivas, tal como a advertência de Georg Rudolf Lind, que afirma que Jacinto do Prado Coelho não chegou a publicar os textos atribuíveis a Vicente Guedes, o que deveria ser feito posteriormente. A questão da dupla autoria será, sem dúvida, a maior de todas as polêmicas que acompanharão este livro em movimento.

Também é curioso notar que, ao contrário das edições que lhe seguem, a primeira organização do Livro do desassossego inclui seis poemas: "Ela canta e as suas notas soltas tecem", "Como quem, roçando um arco às vezes", "Semitis [?] desilientis aquae", "Ninguem. Só eu e o segredo", "Aos deuses uma cousa se agradeça" e "Loura a face que espia". Os outros Livros constituir-se-ão somente de fragmentos em prosa.

Em 1986, a Editora Europa-América faz emergir um novo Livro que colocaria em voga a questão da dupla autoria. O organizador António Quadros propõe, então, uma separação entre uma fase mais antiga e simbolista do livro e outra moderna; assim, o primeiro volume constituise de trechos mais tardios, enquanto o segundo volume apresenta os trechos de "simbolismo decadentista". Para ele, a organização temática de Jacinto do Prado Coelho mistura as duas fases e dilui aquilo que ele considera essencial: a multiplicidade do Livro.

Cria-se aqui a possibilidade de incluir fragmentos da autoria de um outro heterônimo que estava ausente na edição princeps: Vicente Guedes; no entanto, não será dessa vez que ele ganhará o status de autor. Ainda será preciso que decorram cinco anos para que isso aconteça. 
Em 1991, Teresa Sobral Cunha, através da Editorial Presença, organiza a primeira das três edições que serão revistas por ela, compilando mais de 100 textos inéditos. Esta edição traz à tona Vicente Guedes, cujo perfil decadentista-simbolista já havia sido descrito por Jorge de Sena em sua famosa "Introdução", texto em que ele afirmava ser fundamental que se fizesse um estudo futuro sobre a evolução estilística dessa obra, tendo em vista que havia ao menos dois Desassossegos: o escrito nos anos 10, atribuído a Guedes, menos importante por ser excessivamente esteticista e simbolista, e o posterior, que veio à luz sob o heterônimo Soares, e que apresentava um estilo mais modernista. Essa afirmação constituirá uma das principais polêmicas críticas instauradas pelo Livro. Em "Fernando rei da nossa Baviera", Eduardo Lourenço (1986) responde a essa afirmação de Sena, invertendo diametralmente seu ponto de vista: para ele, a essência do Desassossego é decadentista.

Essa edição instaura a principal polêmica que o Livro levantará entre dois estudiosos de F. Pessoa. Em 1992, Richard Zenith, organizador do Livro do desassossego na Inglaterra, em um tumultuoso artigo para a revista Colóquio/Letras, chamado "Um novo Livro do desassossego?", coloca em questão os dois pontos inovadores dessa nova edição: a questão da dupla autoria e o critério cronológico. Para ele, promover Vicente Guedes ao estatuto de co-autor do Livro era um equívoco, na medida em que o próprio F. Pessoa resolveu, mais tarde, atribuir e adaptar os textos iniciais dessa obra a Soares. Entretanto, não chegou a fazê-lo.

Zenith também critica a apresentação dos fragmentos inéditos que foram publicados nessa edição, em que não constava a indícula $L$. do $D$., não podendo, assim, serem incluídos no Livro. Mas admite que quase todos fragmentos aí inseridos poderiam ser do Livro sonhado por Pessoa. "O leitor que confie simplesmente na sabedoria, ou intuição, ou bom gosto, da pessoa que os identificou!"22

O que esse estudioso questiona é o destino que Pessoa gostaria de ter dado a esses fragmentos, pois não foram devidamente revisados e adaptados ao Livro. A postura de Zenith será sempre a de admitir que o Livro do desassossego é constituído somente dos textos organizados por Pessoa para tal - os outros fragmentos seriam apenas uma coletânea de textos dispersos, mas que não estavam destinados a constituir o Livro de Soares.

${ }^{22}$ ZENITH, 1992, p.220. 
Nesse sentido, sua crítica teria sido cabível se F. Pessoa houvesse concluído a tarefa de organização do Livro a que propôs, o que não é possível afirmar com certeza. Como dissemos anteriormente, esse não é um livro acabado, portanto está sujeito às modificações dos critérios dos leitores. Pessoa fez um livro de leitores e não de autor(es), e Zenith parece estar à procura do livro do autor. Pensando na discussão de Blanchot, Zenith quer alcançar fixar aquilo que está a caminho, justamente o que faz do belo o belo: ser inatingível.

Em 1993, Teresa Sobral Cunha, em um artigo denominado "Ainda o Livro do desassossego", publicado na revista Colóquio/Letras, responde às críticas de Richard Zenith, ao defender a necessidade de manter a dupla autoria do Livro e ao explicar os critérios usados para a inserção de trechos não marcados pela indícula, usando uma "gama alargada de critérios de reconhecimento", ${ }^{23}$ tais como a inclusão de variantes, e as notações sobre espécie de escrita, mudança de tinta, entre outros.

Em 1994, a Editora da UNICAMP reedita esta versão de Cunha com fragmentos inéditos. Seguindo o mesmo critério cronológico da edição de 1991, o primeiro volume conta com textos atribuíveis a Vicente Guedes, e o segundo com textos declaradamente escritos por Bernardo Soares. Tal edição apresenta, dentro de um critério, na medida do possível, confiável, o maior número de trechos que poderiam estar conectados ao Livro do desassossego sonhado por F. Pessoa, o que torna possível o estudo evolutivo do desenvolvimento estilístico do Livro inicialmente sugerido por Jorge de Sena.

Em 1997, e mantendo sua postura inicial, Teresa Sobral Cunha publica, pela Editora Relógio d'Água, o primeiro volume do Livro do desassossego, dessa vez com modificações e novos inéditos. Nessa nova edição, a pesquisadora confirma a organização cronológica e a hipótese de dupla autoria. Essa nova edição traria, segundo estudo de Sidónio Paes (2000), 16 trechos inéditos de Guedes, 15 fragmentos retomados do segundo volume na edição de 1994 e a exclusão de 69 trechos editados no primeiro volume de 1994. Ela também inclui, nessa última edição, as variantes que perpassam os fragmentos do Desassossego. No entanto, o segundo volume, destinado a textos que constariam da autoria de Soares, não foi ainda publicado, por questões de direitos autorais, que foram cedidos pelos herdeiros para a Editora Assírio \& Alvim.

\footnotetext{
${ }^{23}$ CUNHA, 1993, p. 218.
} 
Nesse mesmo ano, uma decisão judicial devolve aos herdeiros de Pessoa os direitos autorais, iniciando, assim, uma longa negociação entre eles e a Editora Assírio \& Alvim para publicação da obra completa desse poeta. Por motivos polêmicos, fica a cargo de Richard Zenith a organização da edição do Livro do desassossego. ${ }^{24}$ Fiel a seus primeiros critérios em relação ao Livro, Zenith rejeita a ordem cronológica, pois a considera a mais inadequada, já que nem mesmo Pessoa cogitou desse processo. De fato, em todos os inúmeros planos de edição do Livro realizados por seu autor, não consta nenhum com a preocupação cronológica. Esse pesquisador espera organizar o Livro do desassossego como foi sonhado por F. Pessoa; por isso, como era da vontade expressa de Pessoa, ele evidencia os trechos de Soares, sem se abster, no entanto, de incluir à parte trechos reconhecidamente de Guedes.

Zenith divide o Livro em 3 partes: na primeira, "Autobiografia sem factos", ele agrupa os textos datados da última fase (que considera fielmente de Soares) como esqueleto do que seria um organismo vivo do Livro. No cerne desse esqueleto, agrupou trechos mais antigos e contemporâneos. Para que o leitor não confunda essa ordem subjetiva com uma ordem cronológica, ele desloca todas as datas e notas para o fim do volume. Na segunda parte de "seu" Livro, Richard Zenith organiza os "Grandes Trechos", obedecendo, assim, a um antigo plano de edição de Pessoa, que pretendia agrupar esses textos e formar com eles um livro. Nessa parte, Zenith achou por bem organizá-los não de forma subjetiva, como na primeira, mas por ordem alfabética.

A terceira parte traz um apêndice com 28 trechos em 4 rubricas: I. "Textos que citam o nome de Vicente Guedes"; II. "Matéria fragmentada da 'Marcha fúnebre para o rei Luís Segundo da Baviera'"; III. "Outros textos e fragmentos não integrados no corpus"; IV. "Escritos de Pessoa relativos ao Livro do desassossego".

De um certo modo, essa edição em nada inova as anteriores. Apesar da proposta de organizar a obra como Pessoa a teria feito, é impossível não questionar a validade desse critério, tendo em vista que uma das mais marcantes características de F. Pessoa é exatamente a multiplicidade e não-rigidez de seus conceitos. Como Sidónio Paes bem o assinalou, o jogo da heteronímia é um jogo, e Zenith comete o grande erro de tentar ser Pessoa:

${ }^{24}$ Esta edição foi publicada no Brasil pela Editora Nova Fronteira. 
Ora, se de jogo se trata, quem, de facto, o terá levado ainda mais longe do que Pessoa? Não será o próprio Zenith que quer chegar ao resultado desejado mas não realizado pelo autor? Não Quadros dantes, ou Sobral Cunha agora, a quem importa a investigação histórico-literária, isto é "levar o jogo" até onde Pessoa o deixou, para todo o sempre por cumprir: daí o milagre de "exumar" o corpo de Vicente Guedes, tal qual ficou intocado na arca - túmulo de todos os sonhos de Pessoa por haver. Para Zenith, editar o Livro parece ser um jogo outro; e, em vez de obrar aquele milagre, tenta um ilusionismo de reencarnação. ${ }^{25}$

Ora, se essa obra de Pessoa traz em seu núcleo a moderna possibilidade de ser várias, a gerência de se movimentar em vários sentidos simultaneamente, e nenhuma leitura exclui a outra, sem dúvida, a edição que mais textos apresentar, mais noção nos fornecerá de algumas das reflexões desse autor; em outras palavras, a identidade estilística de Soares e Guedes, ou de Pessoa ortônimo como co-autor do Livro do desassossego, só tem importância na medida em que nos fornece elementos que propiciem a análise, conforme orientação de Jorge de Sena, da evolução do pensamento estético de Pessoa nessa obra. Como afirmar que Soares é Soares e Guedes é Guedes, se Soares, Guedes, Teive e outros mais que ainda estão por se revelar são o que são, e não Campos, Caeiro, Reis, Mora, entre outros? Livro de todos os Pessoas, essa obra entranha e gera as múltiplas metamorfoses que compunham o universo desse autor. A questão da autoria, nesse livro, só adquire importância na leitura, ou seja, os livros que saem desse material são livros de leitores e, a cada nova leitura, outro Livro se comporá de maneira a oferecer sempre um F. Pessoa inicial. Ou, nas palavras de Blanchot, um "livro por vir".

O estudo das edições principais nos propicia verificar como a finalização deste livro a caminho se dá de forma inusitada: como o próprio autor não chegou a organizá-lo, o Livro do desassossego tornou-se literalmente um livro de leitores. A cada organizador, uma nova obra se compõe, e mesmo o leitor leigo, que abre as folhas do livro, pode ler seus fragmentos em uma ordem nova a cada momento. Esta independência quanto à organização traz à tona um livro que, como afirma Blanchot, é espera $^{26}$ e ausência, anônima e totalmente despersonalizada, porque, em sua essência íntima, múltipla:

\footnotetext{
${ }^{25}$ PAES, 2000, p. 199.

26 "A obra é a espera da obra." BLANCHOT, 2005, p. 353.
} 
O livro é sem autor porque se escreve a partir do desaparecimento falante do autor. Ele precisa do escritor, na medida em que este é ausência e lugar da ausência. O livro é livro quando não remete a alguém que o tenha feito, tão puro de seu nome e livre de sua existência quanto do sentido próprio daquele que o lê. [...] "Feito, sendo." ${ }^{27}$

Assim, as variadas e controversas edições nos levam a concluir que o Livro do desassossego não é um livro, mas um projeto de livro, o que é, na realidade, a essência do livro moderno, o que poderemos verificar com mais acuidade ao observar algumas polêmicas críticas quanto ao gênero desta obra.

\section{A forma por vir}

Inquietas também são as discussões sobre a questão do gênero literário no Livro de Guedes e Soares e essa polêmica tornou-se objeto de desassossego e contrapontos de opiniões no cerne crítico dessa obra, cuja multiplicidade faz emergir em conceitos que nem sempre são concordantes, mas todos com idêntica possibilidade de convencer. Diário, romance, narrativa, epopéia, registro lírico, o que, afinal, formaria o material orgânico desse "livro por vir"? O primeiro trecho publicado em 1913, "Na Floresta do Alheamento", já traz em sua gênese esta aporia, pois foi considerado por seu autor como um "drama estático", possuindo, no entanto, fortes indícios líricos. Na edição de poesias completas da Nova Aguilar, organizada por Galhoz (1990), ele é considerado um "poema dramático" e a estudiosa justifica essa escolha através da citação de um dos apontamentos estéticos de Pessoa, em que ele afirma que o drama é a forma máxima de síntese do romance. Assim, entre a narrativa, o drama e a lírica, o primeiro fragmento produz um efeito especulativo em seu leitor, ao apresentar uma linguagem de suspensão, de intervalo entre as impressões externas e as evocações de imagens interiores. De várias posições/lugares ontológicos, ele contempla e vislumbra paisagens interiores, experimentando-se em seres que transmutam a todo momento, num impasse protéico que marcará os outros fragmentos desta obra irrequieta. Ser é estar suspenso, sendo todos e tudo simultaneamente; esta suspensão-dispersão é marcada pelas reticências e evocações vagas

\footnotetext{
${ }^{27}$ BLANCHOT, 2005, p. 336.
} 
que acompanham o texto, podendo, assim, ser e não ser ao mesmo tempo, em um movimento de experimentalismo existencial e lingüístico. Mas o Livro do desassossego é principal e declaradamente um diário, e seu caráter diarístico é discutido, entre outros, por Seixo (1988), Paiva (1988) e Lopes (1984). Seixo afirma que o Livro do desassossego não pode ser considerado como diário, uma vez que não possui um caráter memorialístico e de sobreposição temporal; para essa autora, o Livro é uma ficção, ou seja, um texto que traz, em um entrelaçamento, o fictício e o factício; em outras palavras, um romance. Paiva, por sua vez, aborda a questão da seguinte forma: o que mais se evidencia no Livro é o aspecto diarístico, confessado por Soares algumas vezes, apesar de ter-lhe sido considerado como "artificial demais". Assim, Paiva conclui que se trata de um "diário fingido", ${ }^{28}$ que tenderia à poesia por seu aspecto excessivamente subjetivo ou a um "romance sem ação". Para Lopes, o Livro afasta-se da concepção diarística, uma vez que desconstrói a noção de biografia que evoca uma continuidade temporal. A descontinuidade afastaria essa obra do gênero, pois cada fragmento recomeça um novo registro, independente do anterior.

Como diário, o Livro do desassossego é registro, não de fatos ou ocorrências, mas de sensações e de exercícios da escrita íntima. Sendo assim, este Livro é mais do que um diário, ele é ficção anotada de maneira desconexa, articulada pela escrita de si mesma, ou seja, escrita de uma escrita. Diante dessas reflexões fica impossível não questionar a opção pelo diário como gênero. A relação entre o diário e o fragmento é percebida por Barthes de maneira insólita, em O neutro: para ele, todo fragmento seria uma vontade prévia de escrever um diário. O fragmento, para Barthes, é também a abertura do desejo, o gozo imediato, e é também intervalo, podendo ser visto como um e entre outros, bastando-se a si mesmo e, ao mesmo tempo, podendo ser entrelaçado a outro fragmento, o que imprimiria à obra um caráter de mobilidade. O poético, para Barthes, estaria ligado ao fragmentário, uma vez que a imagem é fragmento em sua essência alegórica e a idéia de totalidade a aniquila. Escolher o diário como expressão metafísica e estética implica em admitir o sujeitoficção como esfacelado, fragmentado, em constante revisão de si mesmo. Escrita de si, suspensão e mobilidade: este é o gênero do Livro pessoano. Diário ou não (mas não podemos perder de vista que o Livro foi tido por Pessoa-Guedes como "diário metafísico das sensações"), o Livro do

${ }^{28}$ PAIVA, 1988, p. 91. 
desassossego emerge de uma tradição literária e filosófica de diários íntimos e de escritas que falam de si. Foucault, ao procurar na história a emergência desta escrita de si, aponta que inicialmente este exercício foi tido como "adestramento de si por si mesmo", ${ }^{29}$ apontado em vários momentos históricos, como nos pitagóricos, nos socráticos, nos cínicos e em Sêneca. Em Epicteto, a escrita está associada à "meditação", "a esse exercício do pensamento sobre si mesmo que reactiva o que ele sabe, se faz presente um princípio, uma regra ou um exemplo, reflecte sobre eles, os assimila, e se prepara assim para enfrentar o real". ${ }^{30}$

Em forma de hypomnemata, notações sobre observações diárias de leituras, conversas, etc., esta escrita de si difere-se dos diários íntimos, que viriam se solidificar posteriormente com a literatura cristã propriamente dita. Ao invés da confissão purificadora, que busca aquilo que está oculto, os hypomnemata dizem o já dito e seu objetivo é "reunir aquilo que se pôde ouvir ou ler, e isto com uma finalidade que não é nada menos que a constituição de si". ${ }^{31}$ Assim, o sujeito colocava-se diante de si próprio, através do logos da tradição, colhendo o conhecimento fragmentário e unificando-o na escrita.

O diário íntimo já pressupõe uma escrita de si que, como adverte Blanchot (2005), está presa a uma cláusula rigorosa: o calendário. Este gênero colocaria seu escritor e a escrita sob a proteção dos dias comuns e do cotidiano e sua maior exigência seria a sinceridade, o que o diferenciaria da narrativa: a narrativa não pode ser verificada, "é o lugar da imantação, que atrai a figura real para os pontos em que ela deve se colocar, respondendo ao fascínio de sua sombra".32

Blanchot afirma que o diário destaca-se por sua insignificância e, em alguns casos, apresenta uma dupla nulidade, como em Amiel, e também podemos dizer seguramente em Pessoa-Guedes-Soares, que adia a vida para escrever e, por isso, não relata uma vivência realmente experimentada. Assim, a escrita do diário íntimo constitui uma forma híbrida, que por se mostrar "aparentemente tão fácil, tão complacente e, por vezes, tão irritante pela agradável ruminação de si mesmo que mantém (como se houvesse o

\footnotetext{
${ }^{29}$ FOUCAULT, 2006, p. 132.

${ }^{30}$ FOUCAULT, 2006, p. 133.

${ }^{31}$ FOUCAULT, 2006, p. 137

32 BLANCHOT, 2005, p. 271.
} 
menor interesse em pensar em si, em voltar-se para si mesmo)", 33 acaba por esconder, em sua complexidade, uma armadilha.

De qualquer forma, tanto o bypomnemata quanto o diário íntimo são formas que se relacionam com a idéia de que, através da escrita, podemos vir a nos conhecer, formas estas que podem ser observadas no Livro do desassossego. Do mesmo modo que o Livro apresenta-se como uma coletânea de registros de sensações internas, tecendo comentários sobre o relato desta mesma escrita, livro-caixa em que os débitos e créditos da escrita são imprimidos, ele é um livro-registro dos dias e dos olhares de seu autor - mas sempre no âmbito da ficção e da ocorrência interna das sensações. A problemática se dá, no entanto, com o status ficcional desta escrita e deste autor, e das experiências estéticas vivenciadas, já que, como em todo o universo pessoano, tudo é fingimento, inclusive a escrita deste fingimento. Assim, os fragmentos vão se colocando como registro de uma ficção que se escreve para se inaugurar, não mais conhecimento e re-conhecimento, mas des-conhecimento, porque nova e estranha, como podemos verificar em um dos fragmentos de Guedes:

Porque não acrediteis que eu escrevo para publicar, nem para escrever nem para fazer arte, mesmo. Escrevo, porque esse é o fim, o requinte supremo, o requinte temperamentalmente ilógico, [...] da minha cultura de estados de alma. Se pego numa sensação minha e a desfio até poder com ela tecer-lhe a realidade interior a que eu chamo ou a A Floresta do Alheamento, ou a Viagem Nunca Feita, acreditai que o faço não para que a prosa soe lúcida e trémula, ou mesmo para que eu goze com a prosa - ainda que mais isso quero, mais esse requinte final ajunto, como um cair belo de pano sobre os meus cenários sonhados - mas para que dê completa exterioridade ao que é interior, para que assim realize o irrealizável, conjugue o contraditório e, tornando o sonho exterior, lhe dê o seu máximo poder de puro sonho, estagnador de vida que sou, burilador de inexactidões, pajem doente da minha alma Rainha, lendo-lhe ao crespúsculo não os poemas que estão no livro, aberto sobre os meus joelhos, da minha Vida, mas os poemas que vou construindo e fingindo que leio, e ele fingindo que ouve, enquanto a Tarde, lá fora não sei como ou onde, dulcifica sobre esta metáfora erguida dentro de mim em Realidade Absoluta a luz ténue e última dum misterioso dia espiritual. ${ }^{34}$

\footnotetext{
33 BLANCHOT, 2005, p. 274.

${ }^{34}$ GUEDES, 1994, p. 111.
} 
Em outras palavras: tudo são símbolos, do próprio autor até a própria escrita deste símbolo, e só no registro que eles se fundam. A realidade interior não é só comunicada, ela é tecida, construída a partir de sua expressão deste "burilador de inexactidões", que tem como atividade criar uma realidade estética e registrá-la ilogicamente. Os fragmentos móveis do Livro expõem esta denúncia da irrealidade factual: os trechos refazem-se em contradições e redimensionam o que já estava dito. Esta escrita de si, neste Livro, é principalmente dispersa e o vário é seu tom dominante. Blanco \& Seixo (1986) ponderam que uma das características que marcam a questão moderna nesse livro de Pessoa é justamente essa diversidade de estilos. Essa variedade se dá não somente como multiplicidade, mas também, segundo Silvina Lopes, como "copresença de forças opostas: movimento de condensação que se conjuga na dispersão, infinitizando-se". ${ }^{35}$ Torna-se impossível um centro homogêneo que recolha essa dispersão; pelo contrário, em um ato convulsivo, a escrita de si volta-se a si mesma, desdobrando e multiplicando esse movimento. Tal estilo convulso e contraditório tem sido motivo de desassossegos não só para seus críticos, mas também para seus tradutores. A tradutora francesa de Pessoa, Françoise Laye, aponta para as dificuldades encontradas em seu ofício, pelo excessivo cerebralismo sustentado por um jogo vertiginoso de metáforas de "ausência":

[...] infinito pessoal, gerúndio (herdado do latim), verbos no modo condicional mas em tempos diversos e com valores diferentes, integrados um no outro como bonecas russas - tudo isto numa única frase de 15 linhas...eis o género de "salto mortal" que o tradutor encontra em cada página. [...] rupturas bruscas, metáforas abruptas, inúmeros neologismos - forjou a sua própria língua para descrever "milimetricamente" (conforme dizia) o movimento profundo de exploração do incógnito. ${ }^{36}$

Ángel Crespo também aponta para as dificuldades de traduzir o Livro, dado o fato de o estilo tender a uma "provisionalidade" e incompletude, de fato, acabam por lhe conferir um caráter extraordinário:

\footnotetext{
${ }^{35}$ LOPES, 1984, p. 20

${ }^{36}$ LAYE, 2000, p. $346 .$.
} 
[...] debido a un verdadero prodigio artístico, las frases incompletas o abocetadas llegan a convertirse, en esta prosa admirable, en recursos estilísticos, tal vez no queridos por su autor, y hasta en insólitas figuras de dicción (o de no dicción). De ahí que, al hacer la traducción, haya respetado escrupulosamente, y sin pretender completarlas o aclararlas, las lagunas y las ambigüedades del texto original. ${ }^{37}$

Essa incapacidade para a unidade pode ser verificada não só em trechos inacabados no livro, mas em fragmentos que Fernando Pessoa deu por terminados, e que, mesmo assim, permanecem em estado de suspensão, tanto tematicamente quanto estruturalmente, já que não trazem a idéia de início ou fim, ou sequer um plano de continuidade. São entremeios, passagens, travessias da escrita - escritura barthesiana, cuja intenção buscada é não a expressão exata do pensamento e da sensação, mas o registro da mobilidade do ser e de sua expressão. Além disso, o livro traz a inscrição de uma escrita que se movimenta em um sentido caleidoscópico de simultaneidade: "caleidoscópio de fragmentadas sequências". ${ }^{38}$

Não é a diversidade, a fantasia e a anarquia dos experimentos que fazem da literatura um mundo disperso. É preciso exprimir-se de outra maneira, e dizer: a experiência da literatura é ela mesma experimento de dispersão, é a aproximação do que escapa à unidade, experiência do que é sem entendimento, sem acordo, sem direito - o erro e o fora, o inacessível e o irregular. ${ }^{39}$

No Livro do desassossego, esta fala de Blanchot se realiza plenamente. Dispersão e inacessibilidade, este livro é peculiarmente um Nada e um Tudo, já que não sendo de fato, mas realizando-se a cada nova leitura, ainda apresenta conturbadas discussões autorais (quem o escreve, afinal? Guedes? Barão de Teive? Soares? Pessoa?), o que lembra a proposta de anonimato no projeto proposto por Mallarmé. A obra ainda evoca os vários outros heterônimos pessoanos, peculiaridade que faria o Livro de Pessoa ser considerado um "livro-síntese", ou como Paiva afirma, "uma espécie de grande mar para onde confluiriam esses diversos rios pessoanos". ${ }^{40}$

\footnotetext{
${ }^{37}$ CRESPO, 1984, p. 20.

${ }^{38}$ GUEDES, 1994, p. 163.

${ }^{39}$ BLANCHOT, 2005, p. 300.

${ }^{40}$ PAIVA, 1988, p. 92.
} 
Na multiplicidade das várias vozes que se inscrevem neste livro, o leitor procura a sua, e o Livro torna-se um objeto móvel sempre buscado e nunca alcançado, tal como o canto das Sereias, citado no início. Síntese e fragmento, este livro sem autor é sempre uma obra do leitor, mas um leitor-mediador, ou seja, que não está na origem nem no fim da leitura, mas em seu meio, tecendo e des-tecendo todos os cantos que ali perpassam. Assim, esse livro se dá conforme o desejo de quem o lê, o que nos remete às discussões de texto-prazer de Barthes, que implica um "jamais se desculpar, jamais se explicar"; ${ }^{41}$ ou seja, o Livro do desassossego torna-se desejo porque é ausência, escapa sempre de se deixar possuir.Em sua multiplicidade, Pessoa-Guedes-Soares compôs um livro absurdo, absurdo esse confessado por Pessoa em vários trechos que afirma que "o absurdo é (o) divino". ${ }^{22}$ Para esse autor, o absurdo-absoluto que Blanchot anuncia é ser e não ser, fazer para depois, penelopeicamente, desfazer; contrapor-se a si mesmo em todos os sentidos: "ter todos os gestos e todas as atitudes de qualquer coisa que nem somos nem pretendemos ser, nem pretendemos ser tomados como sendo". ${ }^{43}$ O estilo no Livro é definido em sentidos divergentes, sem centro de convergências. Sendo assim, todas as críticas são adequadas, nenhuma está certa. O livro-plural de Pessoa, além de pretensamente anônimo e móvel, é inapreensível, afinal, como afirma Guedes, "este livro é um só estado de alma, analisado de todos os lados, percorrido em todas as direcções". ${ }^{44}$

\section{Referências}

BARTHES. Oprazer dotexto. 4. ed. Trad. J. Guinsburg. São Paulo: Perspectiva, 1996.

BARTHES, Roland. O neutro: anotações de aulas e seminários ministrados no Collège de France, 1977-1978. Texto estabelecido, anotado e apresentado por Thomas Clerc. Trad. Ivone Castilho Benedetti. São Paulo: Martins Fontes, 2003.

\footnotetext{
${ }^{41}$ BARTHES, 1996, p. 7.

${ }^{42}$ GUEDES, 1994, p. 206.

${ }^{43}$ GUEDES, 1994, p.206.

${ }^{44}$ GUEDES, 1994. p. 162.
} 
BLANCHOT, Maurice. O livro por vir. Trad. Leyla Perrone-Moisés. São Paulo: Martins Fontes, 2005.

BLANCO, José; SEIXO, Maria Alzira Seixo. Apresentação Crítica. In: Livro do desassossego de Bernardo Soares. Lisboa: Editorial, 1986. p. 11-32.

COELHO, Jacinto do Prado. Fernando Pessoa sempre existiu. In: Livro do desassossego por Bernardo Soares. Lisboa: Ática, 1982. p. VII-XXIII.

CRESPO, Ángel. Introdução. In: Libro del desasosiego de Bernardo Soares. Trad. de Ángel Crespo. Barcelona: Seix Barral, 1984. p. 7-21.

CUNHA, Teresa Sobral. Ainda o "Livro do desassossego". Colóquio/Letras, Lisboa, n. 129-130, p. 217-220, jul.-dez. 1993.

FOUCAULT, Michel. A escrita de si. In: O que é um autor. 6. ed. Trad. António Fernando Cascais e Eduardo Cordeiro. Lisboa: Nova Vega, 2006. p. 127-160.

GUEDES, Vicente; SOARES, Bernardo [Fernando Pessoa]. Livro do desassossego. Recolha, organização e notas Teresa Sobral Cunha. Campinas: UNICAMP, 1994.

KUJAWSKI, Gilberto de Mello. Bernardo Soares e o velho do Restelo.In: Um século de Pessoa. Encontro Internacional do centenário de Fernando Pessoa. Lisboa: Calouste Gulbenkian/Secretaria de Estado da Cultura, 1988. p. 281-282.

LAYE, Françoise. O "Livro do desassossego" de Fernando Pessoa... ou o desassossego do tradutor. Colóquio, Lisboa, n. 155/156, p. 345-347, jan./jul. 2000.

LOPES, Silvina Rodrigues. A ficção da memória e a inscrição do esquecimento no Livro do desassossego. Colóquio, Lisboa, n. 77, p. 19-26, jan. 1984.

LOURENÇO, Eduardo. Fernando, rei da nossa Baviera. Estudos portugueses e africanos, Campinas, n. 8, p. 63-73,1986.

MALLARMÉ, Stéphane. O livro, instrumento espiritual. In: CHIAMPI, Irlemar (Org.). Fundadores da modernidade.São Paulo: Ática, 1991. p.125-128. (Coleção Temas, 25).

MOISÉS, Massaud. O Livro do desassossego: livro-caixa, livro-sensação? In: Um século de Pessoa. Encontro Internacional do centenário de Fernando Pessoa. Lisboa: Calouste Gulbenkian/Secretaria de Estado da Cultura, 1988. p. 87-90.

PAES, Sidónio de Freitas Branco. "Livro do desassossego" - reflexões de um leitor pessoano sobre várias versões. Colóquio, Lisboa, n. 155/156, p. 193-215, jan-jul 2000.

PAIVA, José Rodrigues. O Livro do desassossego: obra de ficção. In: Um século de Pessoa. Encontro Internacional do centenário de Fernando Pessoa. Lisboa: Calouste Gulbenkian/Secretaria de Estado da Cultura, 1988. p. 90- 92. 
PERRONE-MOISÉS, Leyla. Apontamentos sobre a poética do fragmento na prosa de Bernardo Soares. In: Um século de Pessoa.Encontro Internacional do centenário de Fernando Pessoa. Lisboa: Calouste Gulbenkian/Secretaria de Estado da Cultura, 1988. p. 84-87.

ROMERO, Raúl; GARAY, René P. Epifanía y poema en prosa: el Livro do desassossego de Fernando pessoa/Bernardo Soares. Revista do Centro de Estudos Portugueses, Belo Horizonte, v. 25, n. 34, p. 13-22, jan.-dez. 2005.

RUBIM, Gustavo. Livro: o único, o múltiplo, o inexistente. Colóquio, Lisboa, n. $155 / 156$, p. $216-218$, jan./jul. de 2000.

SEIXO, Maria Alzira. Um século de Pessoa. In: Encontro Internacional do Centenário de Fernando Pessoa. Lisboa: Fundação Calouste Gulbenkian/ Secretaria de Estado da Cultura, 1988. p. 93-95.

TABUCCHI, Antonio. Pessoana minima. Escritos sobre Fernando Pessoa. Lousã: Imprensa Nacional/Casa da Moeda, 1984.

ZENITH, Richard. Um novo "Livro do desassossego"? Colóquio/Letras, Lisboa, n. 125/126, p. 219-221, jul./dez. 1992.

\section{Resumo}

Este trabalho pretende problematizar a relação entre o Livro do desassossego e o projeto mallarmeano de um livro-síntese, verificando na obra pessoana aquilo que Blanchot chama de "livro por vir". Através da análise das formas em movimento do Livro, proponho discutir como o autor realiza o conceito de livro, acentuando as polêmicas entre as edições, as discussões sobre o gênero e sobre o fragmento.

\section{Abstract}

This essay intends to question the relation between Livro do desassossego and Mallarme's project of a synthetic book, by verifying in Fernando Pessoa's work what was called by Blanchot of "coming book". By analysing the moving forms in Livro, I intend to discuss how the author works the concept of book, emphasizing the polemics in the editions and the discussions about genre and fragment. 